\title{
TANGGAPAN KETAHANAN PADI (Oryza sativa L.) VARIETAS IPB 4S TERHADAP CEKAMAN SALINITAS DAN CEKAMAN GENANGAN SELAMA FASE VEGETATIF AWAL
}

\section{RESPONSE OF IPB 4S RICE VARIETIES (Oryza sativa L.) TO SALINITY AND WATER LOGGING STRESS DURING INITIAL VEGETATIVE PHASE}

\author{
Yustika Rahayu, Cuneng Nurjanah, Pandu Permana, Nasrudin* \\ Program Studi Agroteknologi, Fakultas Pertanian, Universitas Perjuangan Tasikmalaya \\ Jl. PETA No. 177, Kota Tasikmalaya, Jawa Barat 46115 - Indonesia
}

*Korespondensi: nasrudin@unper.ac.id

\begin{abstract}
ABSTRAK
Upaya dalam pemenuhan kebutuhan pangan berupa beras dapat ditempuh melalui perluasan areal contohnya yaitu lahan salin maupun lahan tergenang. Lahan salin maupun lahan tergenang mempunyai faktor pembatas yang dapat menurunkan pertumbuhan tanaman padi. Tujuan penelitian yaitu: (1). Mengkaji respon ketahanan tanaman padi varietas IPB 4S terhadap cekaman salinitas dan cekaman genangan selama fase vegetatif awal; dan (2). Mengetahui interaksi pengaruh antara cekaman salinitas dan cekaman genangan terhadap pertumbuhan tanaman padi selama fase vegetatif awal. Penelitian menggunakan Rancangan Acak Lengkap (RAL) faktorial dengan dua faktor. Faktor pertama yaitu cekaman salinitas yang terdiri atas 3 level yaitu tanpa salinitas, $\mathrm{NaCl} 10 \%$, dan $\mathrm{NaCl} 20 \%$. Faktor kedua yaitu cekaman genangan yang terdiri atas 3 level yaitu tanpa genangan, digenangi 3 hari sekali, dan digenangi 6 hari sekali. Penelitian diulang sebanyak tiga kali. Pemberian cekaman salinitas dengan konsentrasi 10\% dan 20\% mampu menurunkan beberapa parameter tanaman padi seperti tinggi tanaman, bobot kering tajuk, biomassa tanaman, bagan warna daun, dan luas daun dibandingkan padi yang tidak diberi cekaman salinitas. Perlakuan tanpa cekaman genangan, pemberian cekaman genangan selama 3 hari sekali dan 6 hari sekali tidak memberikan pengaruh terhadap pertumbuhan vegetatif awal tanaman padi varietas IPB 4S.
\end{abstract}

Kata kunci: cekaman abiotik, kelebihan air, $\mathrm{NaCl}$, padi, pangan

\begin{abstract}
Efforts to meet food needs consist of land that can be accommodated through mastery of saline or water flooding. Saline land is also inundated with limiting factors which can reduce the growth of rice plants. The objectives of this research were (1). Study the response of IPB 4S rice plant resistence to salinity and water flooding during initial vegetative phase; and (2). Find out the effect of the interaction between salinity and water flooding on the growth of rice plants during initial vegetative phase. The research used factorial completely ramdomized design (CRD) with two factors. The first factor is salinity stress which consists of 3 levels include non-saline, $10 \% \mathrm{NaCl}$, and $20 \% \mathrm{NaCl}$. The second factor is water logging consists of 3 levels include without water logging, water logging 3 days, and water logging 6 days. The research was repeated three time. The treatments of salinity with $10 \%$ and $20 \%$ determines that rice plants decrease in height parameters, canopy dry weight, biomass, leaf color chart, and leaf area compared to non-saline treatments. The treatment of non water, water logging for 3 days and 6 days does not affect the initial vegetative growth of IPB 4 S variety.
\end{abstract}

Keywords: abiotic stress, food, $\mathrm{NaCl}$, rice, water logging 


\section{PENDAHULUAN}

Padi (Oryza sativa L.) merupakan salah satu tanaman pangan penting di Indonesia. Sebagian besar penduduk di Indonesia mengonsumsi beras sebagai bahan pangan utama yaitu sebesar 114,6 kg kapita-1 $^{-1}$ tahun $^{-1}$ pada tahun 2016 (Kementerian Pertanian, 2016). Jumlah penduduk di Indonesia yang terus meningkat, mengharuskan tersedianya bahan pangan berupa beras yang cukup. Pada tahun 2016, jumlah penduduk Indonesia sebesar \pm 262 juta jiwa dengan laju pertumbuhan penduduk sebesar 1,49\% (BKKBN, 2016).

Salah satu upaya yang dapat dilakukan dalam peningkatan produksi beras yaitu melalui perluasan areal pertanaman. Berkurangnya lahan produktif akibat alih fungsi lahan menyebabkan menurunnya luas areal lahan sehingga mampu menurunkan produksi padi. Pemanfaatan lahan marginal merupakan salah satu solusi yang dapat dilakukan untuk menanam padi. Lahan salin dan lahan yang biasanya tergenang akibat dekatnya lahan pertanian dengan sungai dapat dijadikan lahan potensial untuk budidaya padi.

Meskipun dapat dimanfaatkan sebagai lahan budidaya bagi tanaman padi, lahan salin dan lahan genangan memiliki sejumlah kendala. Lahan salin mengandung garam yang tinggi sehingga mengakibatkan penyerapan hara dan air ke dalam tanaman menjadi terhambat (Nasrudin \& Kurniasih, 2018). Lahan yang tergenang pun memiliki sejumlah kendala seperti terbatasnya kandungan $\mathrm{O}_{2}$ di dalam tanah yang menyebabkan akar tanaman kesulitan untuk melakukan proses respirasi (Sakagami et al., 2013).

Suatu lahan dapat dikatakan mengalami salinitas ketika memiliki kandungan garam sebesar $>4 \mathrm{dS} \mathrm{m}^{-1}$ dan kandungan garam dengan konsentrasi $>10$ dS.m ${ }^{-1}$ mampu menghambat pertumbuhan tanaman seperti mudah terjadinya roboh dan klorosis pada daun padi (FAO, 2005). Ketahanan padi terhadap salinitas berbeda-beda sesuai dengan fase pertumbuhannya. Gupta dan Huang (2014) menyebutkan bahwa cekaman salinitas mampu menurunkan penyerapan air melalui akar dan kehilangan air melalui daun semakin cepat. Hal ini terjadi akibat peningkatan akumulasi garam pada tanah dan tanaman. Saat fase perkecambahan, padi relatif lebih toleran terhadap salinitas. Namun saat dilakukan pindah tanam, cekaman salinitas sangat mempengaruhi pertumbuhan tanaman (Dobermann \& Fairhurst, 2000).

Lahan tergenang merupakan salah satu cekaman abiotik akibat curah hujan tinggi maupun drainase yang buruk 
(Visser et al., 2003). Tanaman dikatakan tergenang apabila hanya sebagian tanaman saja yang tergenangi (Shimamura et al., 2015). Berdasarkan penelitian Syamsuddin et al., (2011) genangan yang melebihi ambang batas dan terjadi secara terus menerus menyebabkan kehilangan hasil. Pada fase pertumbuhan, jumlah anakan akan terhambat akibat cekaman genangan akibat kurangnya udara di tanah.

Selain perluasan areal melalui ekstensifikasi, sistem intensifikasi juga dapat dilakukan yaitu melalui penggunaan varietas unggul. Salah satu varietas unggul yang dapat digunakan yaitu varietas IPB 4S. Pada kondisi optimal, padi varietas IPB 4S memiliki potensi hasil sebesar 10,5 ton $\mathrm{Ha}^{-1}$ dengan waktu panen yang lebih singkat yaitu 112 hst (Institut Pertanian Bogor, 2012). Keunggulan yang dimiliki oleh padi varietas IPB $4 \mathrm{~S}$ diharapkan dapat diaplikasikan pada lahan salin maupun lahan tergenang sehingga tetap dapat berproduksi yang tinggi. Tujuan penelitian yaitu untuk mengkaji ketahanan padi varietas IPB 4S terhadap cekaman salinitas dan cekaman genangan selama fase vegetatif awal dan mengetahui interaksi pengaruh antara cekaman salinitas dan cekaman genangan terhadap pertumbuhan tanaman padi selama fase vegetatif awal.

\section{METODE PENELITIAN}

Penelitian dilaksanakan pada bulan Oktober sampai Desember 2019 di rumah plastik Program Studi Agroteknologi, Fakultas Pertanian, Universitas Perjuangan Tasikmalaya dengan ketinggian tempat $359 \mathrm{mdpl}$.

Bahan-bahan yang digunakan dalam penelitian antara lain: benih padi varietas IPB 4S, $\mathrm{NaCl}$ 10\%, 20\%, pupuk NPK 16:16:16, tanah, dan air. Alat-alat yang digunakan dalam penelitian antara lain: amplop kertas, kertas millimeter blok, oven, bagan warna daun, oven, beaker glass ukuran $1 \mathrm{~L}$, penggaris dan meteran, gelas ukur, polybag ukuran $30 \mathrm{x}$ $40 \mathrm{~cm}$, dan alat tulis.

Penelitian menggunakan rancangan acak lengkap (RAL) faktorial dengan dua faktor. Faktor pertama yaitu cekaman salinitas yang terdiri atas 3 level antara lain S0 (tanpa salinitas), S1 (salinitas 10\%), S2 (salinitas 20\%). Faktor kedua yaitu cekaman genangan yang terdiri atas 3 level antara lain G0 (tanpa genangan), G1 (genangan 3 hari sekali), G2 (genangan 6 hari sekali). Percobaan terdiri atas 9 kombinasi perlakuan. Masing-masing perlakuan diulang sebanyak 3 kali sehingga terdapat 27 unit percobaan.

Sebelum penelitian dimulai, dilakukan proses persiapan. Kegiatan yang dilakukan antara lain persiapan 
media tanam dengan cara mencampurkan tanah dan bahan organik dengan perbandingan 1:1. Setelah media tanam dicampur kemudian dimasukkan ke dalam polybag dengan ukuran 30 x 40 cm. Bersamaan dengan persiapan media tanam, dilakukan persemaian benih padi pada sebuah nampan berisi media tanam yang sama. Pesemaian dilakukan selama \pm 3 minggu.

Benih yang telah disemai kemudian dipindah tanam ke polybag. Setiap polybag diisi sebanyak 3 tanaman. Tanaman dipelihara dengan cara penyiangan dari gulma, pengairan, dan pemupukan. Pupuk yang diberikan yaitu pupuk NPK 16:16:16 dengan dosis 2,69 g polybag-1. Pemberian pupuk dilakukan saat tanaman berumur 7 hst. Selain pemeliharaan tanaman, dilakukan pemberian perlakuan berupa cekaman salinitas dan cekaman genangan. Cekaman salinitas yang diberikan berupa 0\%, 10\%, dan 20\% $\mathrm{NaCl}$ sedangkan cekaman genangan yang diberikan yaitu genangan 3 hari sekali dan 6 hari sekali. Perlakuan genangan yaitu dengan memberikan air pada polybag mencapai ketinggian $5 \mathrm{~cm}$. Perlakuan diberikan saat tanaman berumur 10 hst, kemudian tanaman diamati dengan parameter yang diperlukan selama fase vegetatif awal.

Parameter yang diamati meliputi tinggi tanaman $(\mathrm{cm})$, warna daun, luas daun $\left(\mathrm{cm}^{2}\right)$, panjang akar $(\mathrm{cm})$, bobot kering tajuk (g), bobot kering akar (g), dan biomassa tanaman (g). Pengamatan tinggi tanaman dilakukan dengan mengukur menggunakan meteran mulai dari pangkal batang bawah sampai ujung daun tertinggi. Pengamatan warna daun dilakukan menggunakan alat bagan warna daun yang diamati secara visual. Pengamatan tinggi tanaman dan bagan warna daun dilakukan saat tanaman berumur 21 hst dan 28 hst.

Pengamatan luas daun dilakukan dengan cara menggambar daun di kertas millimeter blok kemudian dihitung luasannya. Panjang akar dilakukan dengan mencabut tanaman sampel kemudian diukur panjang akar menggunakan alat ukur berupa penggaris. Pengamatan panjang akar dan luas daun dilakukan saat tanaman berumur 21 hst dan 28 hst. Pengamatan bobot kering tajuk, bobot kering akar, dan biomassa tanaman dilakukan dengan cara mengurangi kadar air bagian tanaman menggunakan oven pada suhu $80{ }^{\circ} \mathrm{C}$ selama 24 jam. Bagian tanaman yang telah dioven kemudian dilakukan penimbangan menggunakan timbangan analitik. Data yang diperoleh kemudian dicatat pada lembar pengamatan.

Data yang diperoleh dari hasil pengamatan kemudian dilakukan analisis ragam (ANOVA). Apabila terdapat perbedaan diantara perlakuan kemudian dilakukan uji lanjut DMRT pada taraf 
kesalahan 5\%. Pengolahan data statistik menggunakan software STAR (Statistical Tools for Agriculture Research) ver 2.0.1.

\section{HASIL DAN PEMBAHASAN}

Tanaman padi merupakan tanaman yang memiliki kepekaan dalam pertumbuhan terhadap cekaman salinitas maupun cekaman genangan. Setiap fase pertumbuhan tanaman padi memiliki tingkat kepekaan yang berbedabeda. Berdasarkan penelitian yang telah dilakukan, tanaman padi pada fase vegetatif awal memiliki respon negatif terhadap cekaman salinitas ketika umur 21 dan 28 hst. Tabel 1 menunjukkan bahwa tanaman padi yang diberikan cekaman salinitas dengan konsentrasi
$10 \%$ dan $20 \%$ akan menurunkan tinggi tanaman. Hal tersebut disebabkan akumulalsi garam dilingkungan. Akumulasi garam tersebut menyebabkan potensial osmotik di luar sel lebih tinggi dibandingkan potensial osmotik di dalam sel. Aktivitas potensial osmotik tersebut mengakibatkan akar sulit untuk menyerap air dan unsur hara lainnya sehingga pertumbuhan tanaman menjadi terhambat. Harjadi \& Sudirman (1998) menyebutkan bahwa kelebihan $\mathrm{Na}^{+}$akan menyebabkan kerusakan pada sel tanaman sehingga menghambat penyerapan air dan unsur hara. Oleh sebab itu, tanaman yang diberikan cekaman salinitas akan menyebabkan terhambatnya pertumbuhan tanaman.

Tabel 1. Pengaruh cekaman salinitas dan cekaman genangan terhadap tinggi tanaman padi umur 21 hst dan 28 hst

\begin{tabular}{lcc}
\hline \multicolumn{1}{c}{ Perlakuan } & \multicolumn{2}{c}{ Tinggi tanaman (cm) } \\
\cline { 2 - 3 } Cekaman salinitas & $21 \mathrm{hst}$ & $28 \mathrm{hst}$ \\
S0 (tanpa salinitas) & $31,17 \mathrm{a}$ & $45,17 \mathrm{a}$ \\
S1 (salin 10\%) & $14,83 \mathrm{~b}$ & $16,05 \mathrm{c}$ \\
S2 (salin 20\%) & $11,22 \mathrm{~b}$ & $25,50 \mathrm{~b}$ \\
\hline Cekaman genangan & $15,89 \mathrm{p}$ & \\
G0 (tanpa genangan) & $20,94 \mathrm{p}$ & - \\
G1 (genangan 3 hari sekali) & $20,39 \mathrm{p}$ & $28,56 \mathrm{p}$ \\
G2 (genangan 6 hari sekali) & - & $33,50 \mathrm{p}$ \\
\hline Interaksi & $25,24 *$ & $27,67 \mathrm{p}$ \\
\hline CV (\%) & & - \\
\hline Keterangan: (-) tidak ada interaksi; (hst) hari setelah tanam; $(*)$ CV dengan data ditransformasi; angka yang \\
\multicolumn{2}{c}{ diikuti oleh huruf yang sama pada kolom yang sama, tidak beda nyata pada Uji DMRT pada taraf }
\end{tabular}

Tabel 1 menunjukkan bahwa cekaman genangan tidak mempengaruhi tinggi tanaman, artinya antar perlakuan cekaman genangan yang diberikan tidak berbeda nyata pada parameter tinggi tanaman. Tanaman padi umumnya tahan untuk hidup dalam genangan air. Namun, apabila air menggenangi tanaman pada waktu yang lama dengan ketinggian yang cukup tinggi maka tanaman akan 
mengalami kematian. Setyorini \& Rachman (2008) menyebutkan bahwa saat tanaman terendam air dalam jangka waktu yang lama maka suplai $\mathrm{O}_{2}$ dan $\mathrm{CO}_{2}$ menjadi berkurang sehingga akan mengurangi laju fotosintesis pada tanaman. Berkurangnya laju fotosintesis akan menyebabkan tanaman kekurangan cadangan makanan.

Warna daun merupakan indikator untuk menentukan apakah tanaman padi kekurangan atau tercukupi unsur hara khususnya nitrogen (N). Berdasarkan Tabel 2 menunjukkan bahwa perlakuan cekaman salinitas memberikan pengaruh nyata terhadap bagan warna daun. Tanaman padi yang diberikan perlakuan salinitas dengan konsentrasi $10 \%$ dan $20 \%$ menyebabkan penurunan warna daun. Hal tersebut disebabkan oleh penyerapan nutrisi dan air oleh akar. Salah satu unsur hara yang terhambat penyerapannya yaitu hara $\mathrm{N}$ dan $\mathrm{Mg}$ akibat tingginya potensial osmotik diluar sel karena akumulasi garam. Air dan nutrisi khususnya $\mathrm{N}$ dan $\mathrm{Mg}$ yang cukup akan memperbaiki kandungan klorofil daun.

Tabel 2. Pengaruh cekaman salinitas dan cekaman genangan terhadap bagan warna daun padi umur 21 hst dan 28 hst

\begin{tabular}{lcc}
\hline \multicolumn{1}{c}{ Perlakuan } & \multicolumn{2}{c}{ Warna daun } \\
\cline { 2 - 3 } Cekaman salinitas & $21 \mathrm{hst}$ & $28 \mathrm{hst}$ \\
S0 (tanpa salinitas) & $3,11 \mathrm{a}$ & $3,22 \mathrm{a}$ \\
S1 (salin 10\%) & $2,11 \mathrm{~b}$ & $2,00 \mathrm{~b}$ \\
S2 (salin 20\%) & $2,00 \mathrm{~b}$ & $2,11 \mathrm{~b}$ \\
\hline Cekaman genangan & & \\
G0 (tanpa genangan) & $2,11 \mathrm{p}$ & $2,22 \mathrm{p}$ \\
G1 (genangan 3 hari sekali) & $2,56 \mathrm{p}$ & $2,89 \mathrm{p}$ \\
G2 (genangan 6 hari sekali) & $2,56 \mathrm{p}$ & $2,22 \mathrm{p}$ \\
\hline Interaksi & - & - \\
\hline CV (\%) & 28,40 & $17,95^{*}$ \\
\hline Keterangan: (-) tidak ada interaksi; (hst) hari setelah tanam; $\left({ }^{*}\right)$ & CV dengan data ditransformasi; angka yang \\
\multicolumn{2}{c}{ diikuti oleh huruf yang sama pada kolom yang sama, tidak beda nyata pada Uji DMRT pada taraf } \\
\multicolumn{2}{c}{ kesalahan 5\%. }
\end{tabular}

Klorofil daun merupakan unsur penentu tanaman dalam melakukan fotosintesis. Semakin banyak kandungan klorofil suatu tanaman maka akan semakin tinggi laju fotosintesisnya (Gohagu et al., 2016). Seperti diketahui bahwa hara $\mathrm{N}$ mempengaruhi pembentukan klorofil sedangkan hara Mg merupakan inti klorofil. Apabila tanaman kekurangan penyerapan hara dan air akibat akumulasi garam maka tanaman akan terhambat pula dalam sintesis klorofil sehingga warna daun semakin memudar (klorosis) (Ai \& Banyo, 2011).

Tabel 3 menunjukkan bahwa panjang akar tanaman padi umur 21 dan 28 hst tidak dipengaruhi oleh cekaman 
salinitas maupun cekaman genangan. Hal tersebut disebabkan pertumbuhan akar padi tidak dipengaruhi oleh kondisi lingkungan yang kurang optimal. Tanaman akan memanjangkan akarnya untuk mencari nutrisi, namun pada kondisi salinitas dengan konsentrasi 10\% dan 20\% akar masih mampu bertahan untuk hidup. Begitu pula pada kondisi akar yang tergenang dengan ketinggian 3-5 cm selama 6 hari belum berdampak negatif pada pertumbuhan akar tanaman. Oleh sebab itu, pertumbuhan akar tanaman padi selama fase vegetatif awal diduga masih dapat beradaptasi dan mentoleransi terhadap cekaman salinitas maupun cekaman genangan.

Tabel 3. Pengaruh cekaman salinitas dan cekaman genangan terhadap panjang akar umur 21 dan 28 hst serta luas daun padi umur $21 \mathrm{hst}$

\begin{tabular}{|c|c|c|c|}
\hline \multirow{3}{*}{ Perlakuan } & \multicolumn{3}{|c|}{ Parameter pengamatan } \\
\hline & \multicolumn{2}{|c|}{ Panjang akar $(\mathrm{cm})$} & \multirow{2}{*}{ Luas daun $\left(\mathrm{cm}^{2}\right) 21 \mathrm{hst}$} \\
\hline & 21 hst & 28 hst & \\
\hline \multicolumn{4}{|l|}{ Cekaman salinitas } \\
\hline S0 (tanpa salinitas) & $7,56 \mathrm{a}$ & $10,24 \mathrm{a}$ & $9,04 \mathrm{a}$ \\
\hline S1 (salin 10\%) & $7,03 \mathrm{a}$ & $8,18 \mathrm{a}$ & $4,16 \mathrm{~b}$ \\
\hline S2 (salin 20\%) & 7,54 a & $8,73 \mathrm{a}$ & $2,70 \mathrm{~b}$ \\
\hline \multicolumn{4}{|l|}{ Cekaman genangan } \\
\hline G0 (tanpa genangan) & $6,69 \mathrm{p}$ & $8,10 \mathrm{p}$ & $3,86 \mathrm{p}$ \\
\hline G1 (genangan 3 hari sekali) & $7,81 \mathrm{p}$ & $10,01 \mathrm{p}$ & $5,46 \mathrm{p}$ \\
\hline G2 (genangan 6 hari sekali) & $7,63 \mathrm{p}$ & $9,04 \mathrm{p}$ & $6,58 \mathrm{p}$ \\
\hline Interaksi & - & - & - \\
\hline CV (\%) & 30,81 & $18,94^{*}$ & $29,67 *$ \\
\hline
\end{tabular}

Tabel 3 menunjukkan bahwa pertumbuhan luas daun dipengaruhi oleh cekaman salinitas. Padi yang ditanam pada kondisi salinitas dengan konsentrasi 10\% dan 20\% luas daunnya lebih sempit dibandingkan padi yang ditanam tanpa kondisi salinitas saat berumur 21 hst. Menurunnya luas daun menyebabkan terhambatnya proses fotosintesis akibat kandungan klorofil menurun (Nasrudin \& Firmansyah, 2020). Haryadi (2013) menyebutkan peningkatan laju fotosintesis dipengaruhi oleh luasan daun, daun yang luas akibat kesesuaian lingkungan tumbuh. Daun yang sempit disebabkan cekaman salinitas akan menurunkan suplai unsur hara bagi tanaman untuk tumbuh dan berkembang.

Tabel 4 menunjukkan bahwa dalam kondisi tanpa salinitas, tanaman yang digenang selama 6 hari sekali memiliki daun yang lebih luas dibandingkan tanaman yang tidak digenangi dan tanaman yang digenangi selama 3 hari sekali. Saat tanaman 
diberikan cekaman salinitas $10 \%$ pada genangan 3 hari sekali memiliki daun yang lebih luas dibandingkan tanaman yang tidak digenangi dan tidak berbeda nyata saat digenangi 6 hari sekali. Saat tanaman diberikan cekaman salinitas $20 \%$ pada genangan 3 hari sekali memiliki daun yang lebih luas dibandingkan tanaman yang tidak digenangi dan saat digenangi 6 hari sekali. Daun yang lebih luas saat digenangi 3 maupun 6 hari sekali menandakan ketersediaan air meskipun kondisi tanah menjadi jenuh. Keberadaan air mampu membantu tanah untuk melarutkan kadar garam sehingga penyerapan air dan unsur hara lain dapat terpenuhi untuk pertumbuhan tanaman. Nasrudin \& Kurniasih (2018) dalam penelitiannya menyebutkan bahwa keterbatasan air dalam kondisi salinitas mampu menurunkan luas daun dibandingkan ketersediaan air dalam kondisi salinitas. Hal tersebut akibat akar tanaman mampu menyerap air dan unsur hara yang diencerkan melalui bantuan air sehingga pertumbuhan luas daun lebih baik.

Tabel 4. Interaksi cekaman salinitas dan cekaman genangan pada luas daun $\left(\mathrm{cm}^{2}\right)$ padi umur 28 hst.

\begin{tabular}{lcccr}
\hline \multicolumn{1}{c}{ Perlakuan } & \multicolumn{3}{c}{ Cuas daun $\left(\mathbf{c m}^{2}\right)$ umur $\mathbf{2 8}$ hst } \\
\cline { 2 - 4 } & $\begin{array}{c}\text { G0 (tanpa } \\
\text { genangan) }\end{array}$ & $\begin{array}{c}\text { G1 (genangan } \\
\text { 3 hari sekali) }\end{array}$ & $\begin{array}{c}\text { G2 (genangan } \\
\text { 6 hari sekali) }\end{array}$ & \multirow{2}{*}{ Rerata } \\
\hline Cekaman salinitas & & & & \\
S0 (tanpa salinitas) & $21,18 \mathrm{~b}$ & $16,04 \mathrm{c}$ & $31,02 \mathrm{a}$ & 22,74 \\
S1 (10\%) & $0,67 \mathrm{e}$ & $8,92 \mathrm{~d}$ & $4,04 \mathrm{de}$ & 4,54 \\
S2 $(20 \%)$ & $0,23 \mathrm{e}$ & $8,63 \mathrm{~d}$ & $1,82 \mathrm{e}$ & 3,56 \\
\hline Rerata & 7,36 & 11,20 & 12,29 & $10,28(+)$ \\
\hline CV (\%) & $\mathbf{2 8 , 0 7}$ & & & \\
\hline
\end{tabular}

Keterangan: (+) ada interaksi; (hst) hari setelah tanam; angka yang diikuti oleh huruf yang sama tidak berbeda nyata pada Uji DMRT pada taraf kesalahan $5 \%$.

Tabel 5. Pengaruh cekaman salinitas dan cekaman genangan terhadap bobot kering tajuk (g), bobot kering akar (g), dan biomassa (g) padi umur 21 hst.

\begin{tabular}{lccc}
\hline \multirow{2}{*}{ Perlakuan } & \multicolumn{3}{c}{ Parameter pengamatan } \\
\cline { 2 - 3 } Cekaman salinitas & BK Tajuk (g) & BK Akar (g) & Biomassa (g) \\
S0 (tanpa salinitas) & $0,069 \mathrm{a}$ & $0,0286 \mathrm{a}$ & $0,098 \mathrm{a}$ \\
S1 (salin 10\%) & $0,026 \mathrm{~b}$ & $0,0138 \mathrm{a}$ & $0,040 \mathrm{~b}$ \\
S2 (salin 20\%) & $0,015 \mathrm{~b}$ & $0,0178 \mathrm{a}$ & $0,033 \mathrm{~b}$ \\
\hline Cekaman genangan & & \\
G0 (tanpa genangan) & $0,030 \mathrm{p}$ & $0,0196 \mathrm{p}$ & $0,049 \mathrm{p}$ \\
G1 (genangan 3 hari sekali) & $0,038 \mathrm{p}$ & $0,0184 \mathrm{p}$ & $0,057 \mathrm{p}$ \\
G2 (genangan 6 hari sekali) & $0,042 \mathrm{p}$ & $0,022 \mathrm{p}$ & - \\
\hline Interaksi & - & - & $27,19^{*}$ \\
\hline CV (\%) & $29,83^{*}$ & $21,98^{*}$ & $\mathrm{p}$ \\
\hline Keterangan: (-) tidak ada interaksi; (BK) bobot kering; $(*)$ CV dengan data ditransformasi; angka yang diikuti \\
\multicolumn{2}{c}{ kleh huruf yang sama pada kolom yang sama, tidak beda nyata pada Uji DMRT pada taraf }
\end{tabular}


Tabel 5 menunjukkan bahwa tanaman padi berumur 21 hst yang diberikan cekaman salinitas $10 \%$ dan $20 \%$ mampu menurunkan bobot kering tajuk dan biomassa tanaman. Hal tersebut diduga dipengaruhi oleh luas daun padi saat tanaman yang ditanam pada kondisi salin lebih sempit sehingga menyebabkan penangkapan matahari terbatas. Terbatasnya intensitas matahari pada tanaman yang tercekam salin menyebabkan penurunan laju fotosintesis. Laju fotosintesis yang lebih rendah menyebabkan fotosintat pun rendah. Fotosintat yang terbatas menyebabkan translokasinya pun terbatas pada bagian tanaman sehingga biomassa tanaman pada tanaman dalam kondisi salinitas $10 \%$ dan $20 \%$ pun menurun. Cekaman salinitas lebih berpengaruh terhadap pertumbuhan padi selama fase vegetatif awal. Disisi lain, cekaman genangan juga mampu mempengaruhi pertumbuhan tanaman apabila waktu dan tingkat genangan semakin tinggi.

\section{KESIMPULAN}

Berdasarkan penelitian yang telah dilakukan, dapat diketahui bahwa padi varietas IPB $4 \mathrm{~S}$ memiliki ketahanan terhadap cekaman genangan yang ditunjukkan dengan tidak adanya pengaruh nyata pada berbagai parameter yang diamati. Berbeda dengan cekaman genangan, cekaman salinitas sangat berpengaruh terhadap pertumbuhan padi varietas IPB 4 S selama fase vegetatif awal. Hal tersebut ditunjukkan dengan perbedaan pada parameter tinggi tanaman, luas daun dan bagan warna daun saat tanaman berumur 21 dan 28 hst, serta bobot kering tajuk dan biomassa tanaman saat tanaman berumur 21 hst. Interaksi cekaman salinitas dan cekaman genangan sangat mempengaruhi luas daun padi pada umur 28 hst. Pemberian cekaman salinitas dengan konsentrasi $10 \%$ dan $20 \%$ menunjukkan bahwa tanaman padi menurun pada parameter tinggi tanaman, bobot kering tajuk, biomassa tanaman, bagan warna daun, dan luas daun. Pemberian cekaman genangan selama 3 hari sekali dan 6 hari sekali tidak memberikan pengaruh terhadap pertumbuhan vegetatif awal tanaman padi varietas IPB 4 S.

\section{DAFTAR PUSTAKA}

Ai, N. S., \& Banyo, Y. (2011). Konsentrasi klorofil daun sebagai indikator kekurangan air pada tanaman. Jurnal Ilmiah Sains 22(1), 166-173. http://doi.org/10.35799/jis.11.2.2 011.202

BKKBN. (2016). Laju Pertumbuhan penduduk 4 juta per tahun. URL: https://www.bkkbn.go.id/detailpo st/laju-pertumbuhan-penduduk-4- 
juta-per-tahun (diakses pada 23 Desember 2019).

Dobermann, A., \& Fairhurst, T.H. (2000). Rice: nutrient disorders and nutrient management. International Rice Research Institute.

FAO. (2005). 20 Hal untuk diketahui tentang dampak air laut pada lahan di Provinsi NAD. URL: http://www.fao.org. (diakses pada 23 Desember 2019).

Gohagu, Y., Ai, N. S., \& Siahaan, P. (2016). Konsentrasi klorofil pada beberapa varietas tanaman Puring (Codiaeum varigatum L.). Jurnal Mipa Unsrat 5(2), 76-80. http://doi.org/10.35799/jm.5.2.20 16..12964

Gupta, B, \& Huang, B. (2014). Mechanism of salinity tolerance in plants: physiological, biochemical, and molecular characterization. International Journal of Genomics 3(2014), 1-18. https://doi.org/10/1155/2014/70 1596

Harjadi, S. S., \& Sudirman. (1998). Fisiologi stress lingkungan. PAU Bioteknologi Institut Pertanian Bogor, Bogor.

Haryadi, H. (2013). Pengukuran luas daun dengan metode Simpson. Jurnal Anterior 12 (2), 1-5.

Institut Pertanian Bogor. (2012). IPB resmi meluncurkan varietas padi unggul. URL: https://fateta.ipb.ac.id/ipb-resmimeluncurkan-varietas-padi-

unggul/ (diakses pada 23 Desember 2019).

Kementerian Pertanian. (2016). Data Kementan selaras dengan data BPS. URL: http://www.pertanian.go.id/ap_po sts/detil/1181/2017/09/28/09/3 0/05/Data\%20Kementan\%20Sela ras\%20Dengan\%20Data\%20BPS (diakses pada 23 Desember 2019)

Nasrudin, \& Firmansyah, E. (2020). Analisis pertumbuhan tanaman padi varietas IPB 4 S pada media tanam dengan tingkat cekaman kekeringan berbeda. Jurnal Galung Tropika 9(2), 125-134. http://dx.doi.org/10.31850/jgt.v9i 2.604

Nasrudin, \& Kurniasih, B. (2018). Growth and yield of Inpari 29 rice varieties on raised-bed and different depths of sunken-bed in saline field. Jurnal Ilmu Pertanian (Agricultural Science) 3(3), 135-145. https://doi.org/10.22146/ipas.38 736

Sakagami, J., Joho, Y., \& Sone, C. (2013). Complete submergence escape with shoot elongation abiliy by underwater photosynthesis in Africa rice, Oryza glaberrima Steud. Field Crop Research 152(3), 17-26. https://doi.org/10.1016/j.fcr.2012 .12 .015

Setyorini, D, \& Rachman, A. S. (2008). Pengelolaan hara mineral tanaman padi. In Padi-Inovasi Teknologi dan Ketahanan Pangan Buku I. Balai Besar Penelitian Tanaman Padi. Badan Penelitian Dan Pengembangan Pertanian.

Shimamura, S., Mochizuki, T., Nada, Y., \& Fukuyama, M. (2015). Secondary aerenchyma formation and its relation to nitrogen fixation in root nodules of soybean plants (Glycine $\max$ ) grown under flooded conditions. Plant production science 5(4), 294-300. https://doi.org/10.1626/pps.5.294 
Syamsuddin, Indradewa, D., Sunarminto, B. H., \& Yudono, P. (2011). Pertumbuhan dan hasil dua kultivar padi dan berbagai jarak tanam pada sistem pengairan genangan dalam parit. Jurnal Agroland 18(3), 155-161.
Visster E .J. W., Voesenek, L. A. C. J., Vartapetian, B. B., \& Jackson, M. B. (2003). Flooding and Plant Growth. Annals of Botany 91(3), 107-109. https://doi.org/10.1093/aob/mcg 014 